\title{
Packaging and Cold Storage of Fresh Products
}

\author{
MC Ndukwu* \\ Michael Okpara University of Agriculture, Nigeria
}

Submission: October 2, 2017; Published: December 07, 2017

*Corresponding author: MC Ndukwu, Department of Agricultural and Bioresources Engineering, Michael Okpara University of Agriculture, Umudike, Umuahai Abia, Nigeria, Email: ndukwumcu@gmail.com

\section{Abstract}

Advances in packaging technologies offers new prospects in prolonged cold storage of fresh products. Gaseous combination of $\mathrm{CO}_{2}, \mathrm{O}_{2}$ or $\mathrm{N}_{2}$ at different level of concentration in modified atmospheric packaging (MAP) is the most adopted treatment. However $\mathrm{CO}_{2}, \mathrm{O}_{2}$ and $\mathrm{N}_{2}$ gases in MAP systems in most cases has not given satisfactory appearance despite improved stability as revealed from the reviews. Therefore further research in other possible gases is very important. Research effort should not be limited to stability and appearance during preservation but also retaining this attributes during display even for a length of period of sale. Technologies like injecting Nano trace elements in the packaging and storage procedure can improve the appearance and produce designer effects as obtainable in other processes.

Keywords: Modified atmospheric packaging; Storage; Fresh meat; Fresh vegetables; Fresh fruits.

\section{Introduction}

Packaging plays a major role in the storage, marketing, distribution and handling of agricultural and food products [1]. It creates the needed balance over time between the bioenvironmental factors and the product for extended shelf life. Additionally it does not only protect the product from impurity but also ease the transportation of the products and prevent physical damage. Also, it persuades and provides other necessary information that identifies the product for both the distributor and the consumer. Different materials are involved or adopted in the packaging of fresh products and research has shown that each has its effects on the products. Some of the material used includes baskets, bags of different material, corrugated boxes of different kind, polymeric films, crates, trays, pouches, sheets of different material, metal containers etc [2].

Broadly agricultural products can either be dried and packaged for onward distribution or packaged and cold preserved in the fresh form. Cold storage has always been the first choice and the simplest method applied for fresh food storage like meat and vegetables due to the retention of most of its bio-composition prior to processing [3]. However research has shown that cold storage alone cannot properly preserve some fresh products and there is the need to combine cold storage with advanced packaging procedure [4]. Conversely this review looks at packaging methods used for cold products and research findings on the effects on physiochemical and organoleptic properties of these products.

\section{Mechanism of packaging}

Mechanism or procedure of packaging can range from simple or traditional packaging procedure like loading in crates, pallets or shrink wrapping (SWP) to vacuum packaging (VP) or modified atmospheric packaging (MAP). While loading in crates fits for bulk packaging [5], VP are comparatively used for smaller quantity placed in air tight container which must be sealed after certain amount of oxygen is sucked out $[6,7]$. Similarly SWP uses a film and sealing bar under elevated temperature to fit on the product with air escaping from the tiny holes on the film surfaces that serves as the vents. However these holes makes the packaging not to be perfectly sealed and vulnerable. MAP is a bit more versatile in the effect that SWP or VP is a straight jacketed method of removing oxygen and sealing the container but MAP can be tailored to a particular product with the required gaseous combination and at a desired quantity to produce the desired gaseous environment for increased shelf life [8]. Leakage can be easily detected in MAP than VP due to presence of gases.

\section{Effect of VP and MAP on Cold Stored Products}

Packaging procedures can distort or improve the physiochemical and organoleptic properties of the packaged product. For instance in VP as the air is removed from the packaged materials, the pressure will decrease leading to the collapse of the material around the packaged product and can distort the appearance like flesh products or the product 
can deform as a result of the pressure. The same effect can be obtained in MAP if the ratio of the product and gas like $\mathrm{CO}_{2}$ is not adequate the package can also collapse due to solubility of $\mathrm{CO}_{2}$ in wet environment.

Günşen et al. [9] stated that for fresh food this ratio must be at most 3:1.These effects of VP and MAP has been studied at various gaseous environment in the case of MAP for different cold stored products. Günșen et al. [9] studied shelf life of fish in VP and MAP using $\mathrm{CO}_{2}$ and nitrogen $\left(\mathrm{N}_{2}\right)$ gas combination and concluded that MAP extended the shelf life of fish by $57 \%$ over VP. Kondratowicz et al. [7] noticed a progressive increase of $\mathrm{pH}$ value, hydrolytic status of intramuscular lipids and darker colour of turkey breast muscles cold stored under MAP with $\mathrm{O}_{2}$ and $\mathrm{N}_{2}$ gas combination after some time. Daszkiewicz et al. [3] reported a gradual increase in the drip loss of roebuck meat in MAP with $\mathrm{CO}_{2}$ and $\mathrm{N}_{2}$ gas combination. Alaid et al. [10] found a significant effect of packaging methods on the total soluble solids and water activity of cold stored date fruits. Fernandes et al. [11] studied the stability of lamb loin under cold storage and packaged using VP, and MAP $\left(75 \% \mathrm{O}_{2}+25 \% \mathrm{CO}_{2}\right.$ and $100 \%$ $\mathrm{CO}_{2}$ ). They evaluated microbiological, physical, chemical and sensory attributes and concluded that $100 \% \mathrm{CO}_{2}$ MAP provided better stability but lower appearance preference. Fernandes et al. [12] studied the stability of cold stored lamb loin with VP systems and discovered increased microbial count after a week. Other studies that investigated effect of packaging on fresh stored products can be found in Krala L [13], Pfeiffer and Menner [14], Devlieghere et al. [15], Skandamis and Nychas [16] etc.

\section{Conclusion and Future Trend}

It is imperative from these studies that MAP (gaseous combination) provides more extended shelve life for fresh products in terms of physiochemical and biological composition but in most cases appearance is compromised especially in meat. Gaseous combination of $\mathrm{CO}_{2}, \mathrm{O}_{2}$ or $\mathrm{N}_{2}$ is most adopted treatment. However, the review showed that this dominant application of $\mathrm{CO}_{2}, \mathrm{O}_{2}$ and $\mathrm{N}_{2}$ gases in MAP systems in most cases has not given satisfactory appearance despite improved stability. Therefore it is required to try other gaseous combination options.

Research effort should not be limited to stability and appearance during preservation but also retaining this attributes during display even for a length of period of sale. Technologies like injecting Nano trace elements in the packaging and storage procedure can improve the appearance and produce designer effects as obtainable in other processes.

\section{References}

1. Pathare PB, Opara UL, Vigneault C, Delele MA, Al-Said FAJ (2012) Design of packaging vents for cooling fresh horticultural produce. Food and Bioprocess Technology 5(6): 2031-2045.
2. Pascall MA (2010) Packaging for fresh vegetables and vegetable products. In N. Sinha (Eds.), Handbook of vegetables and vegetable processing Oxford: Wiley-Blackwell.

3. Daszkiewicz T, P Janiszewski, J Kondratowicz (2008) Changes in Chemical Composition of Meat from Roe Deer (CapreolusCapreolusL.) Bucks during Cold Storage under Vacuum and Modified Atmosphere. Pol JFood Nutr Sci 58(3): 331-334.

4. Goulas A (2007) Combined effect of chill storage and modified atmosphere packaging on mussels (Mytilusgalloprovincialis) preservation. Packaging Technology and Science. Published online in Wiley Inter Science.

5. Pathare PB, Opara UL (2014) Structural design of corrugated boxes for horticultural produce: A review. bio systems engineering 125(2014): 128-140.

6. Church N (1998) MAP fish and crustaceans-sensory enhancement Food Science and Technology Today 12(2): 73-83.

7. Kondratowicz J, I Chwastowska, P Matusevičius, J Gardzielewska, K Skibniewska (2006) Effect of the Packaging Method on the Sensory and Microbiological Properties of Broiler Chicken Breast Muscles Stored In Controlled Atmosphere. Veterinarija Ir zootechnika t 33(55).

8. Koski DV (1988) is current modified/controlled atmosphere packaging technology applicable to the U.S. food market? Food Technology, 9: 54.

9. GünșenU, A Özcan, A Aydın (2011) Determination of Some Quality Criteria of Cold Storaged Marinated Anchovy under Vacuum and Modified Atmosphere Conditions. Turkish Journal of Fisheries and Aquatic Sciences 11: 233-242.

10. Aleid SM, AM Elansari, Tang Zhen-Xing, AA Sallam (2014) Effect of Cold Storage and Packing Type on Khalas and Sukkary Dates Quality. Advance Journal of Food Science and Technology 6(5): 603-608.

11. Fernandes Rde P, Freire MT, de Paula ES, Kanashiro AL, Catunda FA et al. (2014) Stability of lamb loin stored under refrigeration and packed in different modified atmosphere packaging systems. Meat Science 96(1): 554-561

12. Fernandes RPP, Freire MTA, Guerra CC, Carrer CC, Balieiro JCC, et al (2012). Estabilidadefísico-química, microbiológica e sensorial de carne ovinaembalada a vácuoestocada sob refrigeração. Ciência Rural $42(4)$.

13. Krala L(1999) The effect of controlled and modified atmosphere on the properties of cold-stored chicken meat (in Polish). Wyd Nauk PolitechnikiŁódzkiej, Rozpr Nauk 255: 5-141.

14. Pfeiffer T, Menner M (1999) Modified atmosphere packaging for self-service fresh meat change of gas atmosphere during storage. Fleischwirtschaft 79(12): 79-84.

15. Devlieghere F, Debevere J, Van Impe J (1998) Concentration of carbon dioxide in the water-phase as a parameter to model the effect of a modified atmosphere onmicroorganisms. Int J Food Microbiol 43(1/2): 105-113.

16. Skandamis PN, Nychas GJ (2002) Preservation of fresh meat with active and modified atmosphere packaging conditions. Int J Food Microbiol 79(1-2): 35-45. 
This work is licensed under Creative Commons Attribution 4.0 License DOI: $10.19080 / \mathrm{NFSIJ} .2017 .04 .555632$

\section{Your next submission with Juniper Publishers will reach you the below assets}

- Quality Editorial service

- Swift Peer Review

- Reprints availability

- E-prints Service

- Manuscript Podcast for convenient understanding

- Global attainment for your research

- Manuscript accessibility in different formats ( Pdf, E-pub, Full Text, Audio)

- Unceasing customer service

Track the below URL for one-step submission https://juniperpublishers.com/online-submission.php 